\title{
SELECTED NUTRTIIONAL BEHAVIORS AND THE LEVEL OF PHYSICAL ACTIVITY OF HIHH SCHOOL STUDENTS
}

\author{
Joanna Ratajczak, 1, A, D, E Katarzyna Rucińska,, D Marek Kolbowicz, , B, C \\ Tomasz Zalewski2, B, C \\ 1 University of Szczecin, Faculty of Health and Physical Education, Poland \\ 2 University of Szczecin, Faculty of Geosciences, Poland \\ A Study Design; ${ }^{\mathrm{B}}$ Data Collection; ${ }^{\mathrm{C}}$ Statistical Analysis; ${ }^{\mathrm{D}}$ Manuscript Preparation; E Founds Collection \\ Address for corpespondence: \\ Joanna Ratajczak \\ University of Szczecin, Faculty of Health and Physical Education \\ Al. Piastów 40B, building 6, 71-065 Szczecin, Poland \\ E-mail: joanna.ratajczak@usz.edu.pl
}

\begin{abstract}
Ahstract The aim of the study was to assess selected nutritional behaviors and the level of physical activity of high school students in the West Pomeranian Voivodship. The research included questionnaires regarding the consumption of breakfast, detailing school days and weekends, the amount of vegetables, fruit, sweets and sugary drinks consumed, as well as questions about physical activity during school and extracurricular classes, intensity of exercises and participation of parents in joint sport. Anthropometric measurements were performed including: body weight, height, BMI, fat mass, lean mass, muscle mass. Body composition analysis was based on the bio-electrical impedance analysis (BIA). There were many irregularities in the way students were eating: lack of breakfast, too little consumption of vegetables and fruits and frequent consumption of sweets and sugary drinks. Physical activity in the majority of students was at a correct level. Despite the nutritional mistakes made, the average BMI of the tested students was correct.
\end{abstract}

Key worlds children, nutrition, physical activity

\section{Introduction}

The way we eat has a huge impact on our current state of health and has an impact on our condition in the future. Childhood and the period of early youth are the most appropriate period for shaping proper eating habits that ensure health, while mistakes made during this time bring negative effects in adulthood. In addition, the eating habits of children and youth are usually repeated in later life. Nutritional behaviors depend on a variety of aspects, i.e. economic, political, cultural, geographical, social and religious aspect (Ward-Begnoche, Gance-Cleveland, 2005; Jeżewska-Zychowicz, 2004). The habits of parents and carers, advertising of food products and current dietary fashions, fulfill an overriding role in the nutrition of children and adolescents. Developments in civilization have promoted changes in eating behaviors as well as in the whole lifestyle, resulting in a progressive 
development of diet-related diseases (Gronowska-Senger, 2007; Trujillo, Davis, Milner, 2006; Zimna-Walendzik, Kolmaga, Tafalska, 2009).

Diet-related diseases, i.e. cardiovascular diseases, diabetes, osteoporosis, obesity, gastrointestinal cancers, anemia, tooth decay etc., are increasingly common in all age groups.

The percentage of obesity, which is currently referred to as an epidemic (Barry, 2000), is particularly dynamic. Obesity is a systemic disease that is characterized by excess body fat in the body. It has been shown that a child who is obese at the age of $10-13$ is about 6 times more likely to remain obese in the future compared to a child with normal weight (Epstein, 1996). This is due to the fact that the number of fat cells cannot be reduced, even as a result of slimming treatment - then only the fat content is reduced. Therefore, in children and adolescents who experience excessive body mass or obesity, a large number of adipose tissue cells will remain for a lifetime, which causes a high inclination to obesity even with small dietary mistakes in adulthood.

The main cause of obesity as well as other diet-related diseases are abnormal eating habits. Incorrect diet not only causes the development of these diseases, but also negatively affects physiological development, slows down the ability to learn and reduces concentration (Harton, Sa'eed Bawa, Weker, 2002; Szczepaniak, Flaczyk, Górecka, 2002).

According to the basic principles of proper nutrition, children should consume at least 4-5 meals to provide all the necessary nutrients, and breaks between them should be no more than 4 hours. Vegetables and fruits should be consumed as often and as much as possible. The menu should contain wholegrain cereal products, dairy products, fish, legume seeds, eggs and lean meats. Young people should limit animal fats in favor of vegetable oils, avoid sugar (sweets and sugary drinks), salt (salty snacks, fast food) and drink at least 1.5 litres of water a day (Zasady Prawidłowego Żywienia, 2016).

Typical mistakes made by adolescents include a lack of variety and a monotonous menu, a high consumption of simple sugars - sweets, sweetened carbonated beverages, meat products, fats (Gawęcki, Roszkowski, 2009) and increasingly popular fast foods (Gawęcki, Roszkowski, 2009; Wierzbicka, Roszkowski, 2005; Świderska-Kopacz, Marcinkowski, Jankowska, 2008; Szponar, Rychlik, 2000; Wierzbicka, Stosio, 2007). Young people usually eat too little fruit, vegetables, dairy products, whole grains and fish products. Often observed issues include irregularity in eating meals (Gawęcki, Roszkowski, 2009; Wierzbicka, Roszkowski, 2005; Gronowska-Senger, 2001; llow, Rogulska-llow, Sarzała-Kruk, Biernat, 2008; Jeżewska-Zychowicz, 2007), skipping meals (Gawęcki, Roszkowski, 2009; Wierzbicka, Roszkowski, 2005; llow et al., 2008; Hamułka, Gronowska-Senger, Tomala, 2002; Szewczyński, Ostrowska, Gajewska, 2005; Rampersaud, Pereira, Girard, Adams, Metzl, 2005; Gould, Russell, Barker, 2006; Dzielska, Kołoło, Mazur, 2008), in particular breakfast before class activities or snacking between meals (llow et al., 2008; Jeżewska-Zychowicz, 2007; Szewczyński et al., 2005). This leads to too low or high energy supply, excess fat and sucrose, too little fiber, a shortage of minerals such as zinc, magnesium, copper, calcium, iron and $B$ vitamins, vitamin C, D and polyunsaturated fatty acids (Omega 6 and Omega 3) (Jarosz, Bułhak-Jahymczyk, 2008).

Overweight and obesity during childhood and early childhood beyond abnormal nutrition also results from low activity levels or inactivity and the increasing popularity of a sedentary lifestyle (Knapik, Plinta, Saulicz, Kuszewski, 2004; Brytek, 2005; Korczak, 2000). Low physical activity, in addition to increasing the risk of developing obesity, increases the likelihood of coronary heart disease, diabetes, hypertension and osteoporosis (Zielona Księga..., 2005). Physical activity is a key element of a healthy lifestyle, especially for children and adolescents. It is an 
essential factor in normal physical, mental and social development (Knapik et al., 2004; Nosko, 1990; Riddoch, 1998; Żołnierczuk-Kieliszek, 2002).

The aim of the study was to analyze the eating habits and physical activity of high school students in cities of various sizes and check the composition of the body in relation to the diet.

\section{Materials and methods}

A diagnostic survey method was used and the students were asked about their eating habits and physical activity based in the questionnaire. Using the electrical bioimpedance method, a body composition analysis including body weight, BMI, fat mass, lean mass and muscle mass was performed. The student's body height was measured in accordance with the principles of anthropometry.

\section{Findings}

The study involved 3,537 high school students (Table 1) between 15 and 20 years of age (Table 3). The average age was 17 years (Figure 2). In the study group, $46.7 \%$ were girls and $53.5 \%$ boys (Figure 1). Most of the students came from medium-sized towns (from 11,000 to 19,000 inhabitants). $23.95 \%$ were from towns up to 11,000 inhabitants, $23.10 \%$ from big cities from 20,000 to 50,000 inhabitants, and $23.66 \%$ from very big cities (over 50,000 inhabitants) (Table 2, Figure 3).

Table 1. Group characteristics - number of students in individual poviats

\begin{tabular}{|c|c|c|c|c|c|}
\hline No. & District & $n$ & No. & District & $n$ \\
\hline 1. & Choszczno & 187 & 11. & Darłowo & 187 \\
\hline & Szczecin & 341 & 12. & Pyrzyce & 142 \\
\hline & Świdwin & 130 & 13. & Świnoujście & 159 \\
\hline 4. & Chojna & 180 & 14. & Kamień Pomorski & 151 \\
\hline 5. & Police & 164 & 15. & Łobez & 120 \\
\hline 6. & Złocieniec & 155 & 16. & Nowogard & 88 \\
\hline & Białogard & 95 & 17. & Kołobrzeg & 187 \\
\hline 8. & Myślibórz & 147 & 18. & Biały Bór & 210 \\
\hline & Trzebiatów & 186 & 19. & Koszalin & 194 \\
\hline 10. & Wałcz & 212 & 20. & Stargard & 302 \\
\hline \multicolumn{6}{|c|}{ Total: 3,537} \\
\hline
\end{tabular}

Table 2. Group characteristics - number of students in individual districts, taking into account the number of inhabitants

\begin{tabular}{clrc}
\hline No. & \multicolumn{1}{c}{ Town/City } & $n$ & $\%$ \\
\hline 1. & Small up to 11,000 & 847 & 23.95 \\
2. & Medium 11-19,000 & 1,036 & 29.29 \\
3. & Big 20-50,000 & 817 & 23.10 \\
4. & Very big over 50,000 & 837 & 23.66 \\
\hline Total & & 3,537 & 100.00 \\
\hline
\end{tabular}

Source: own study. 
Table 3. Age of students in individual districts, including the number of inhabitants

\begin{tabular}{lcccccc}
\hline \multicolumn{1}{c}{ Town/city } & $\mathrm{n}$ & $\mathrm{x}$ & $\mathrm{SD}$ & $\mathrm{v}$ & $\min$ & $\max$ \\
\hline Small & 847 & 17.03 & 0.97 & 5.70 & 15 & 20 \\
Medium & 1036 & 16.85 & 0.97 & 5.76 & 15 & 19 \\
Big & 817 & 16.99 & 1.07 & 6.28 & 15 & 20 \\
Very big & 837 & 16.95 & 1.03 & 6.07 & 15 & 20 \\
\hline Total & 3,537 & 16.95 & 1.01 & 5.95 & 15 & 20 \\
\hline
\end{tabular}

$\mathrm{n}$ - number; $\mathrm{x}$ - arithmetic mean; SD - standard deviation; $v$ - coefficient of variation; min - minimum sample value; max - maximum sample value.

Source: own study.

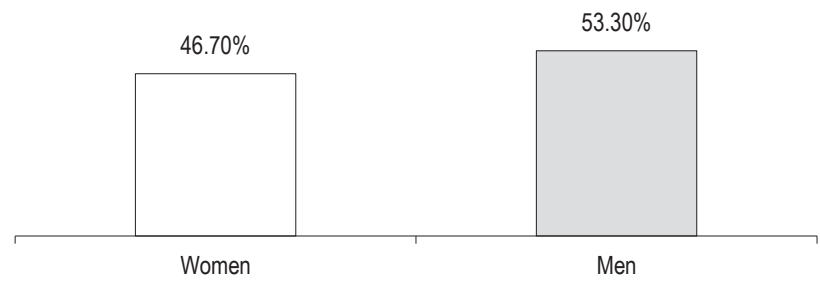

Figure 1. Gender of the students

Source: own study.

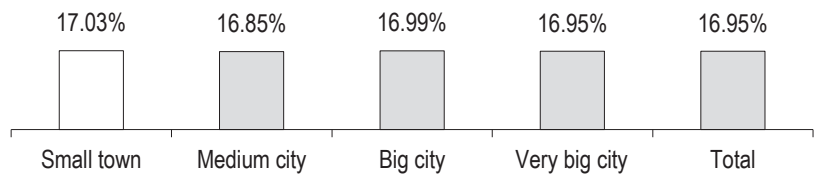

Figure 2. Age of students in individual districts, taking into account the number of inhabitants

Source: own study.

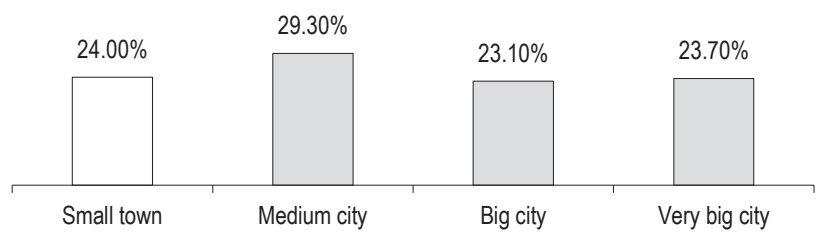

Figure 3. Place of residence of the students

Source: own study. 
The questionnaire asked about eating habits - breakfast, the share of fruit and vegetables in the diet, consumption of sweets, and the physical activity practiced by the students and their parents.

When asked about breakfast, $15 \%$ of the students answered that they never eat breakfast on school days, $57.5 \%$ eat breakfast each day, and the remaining 27.5\% eat 2-3 times within 5 days (Figure 4). At weekends, 9.3\% of students do not eat breakfast, $81.6 \%$ always eat it, others only eat on Sunday (3.8\%) or on Saturday (5.3\%).

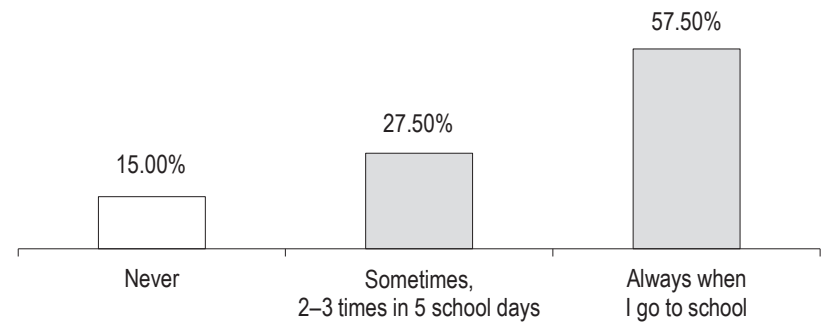

Figure 4. Frequency of breakfast (i.e. something more than a glass of milk, tea or other drink) on school days Source: own study.

Every day, $23.3 \%$ of the students eat fruit, $11.3 \%$ of which more often than once a day, almost $15 \%$ eat fruit 5-6 times a week, and $42.8 \%$ eat fruit from 2 to 4 times a week. The group also included persons (12.8\%) who eat fruit only once a week, and even less frequently (5.8\%) (Figure 5).

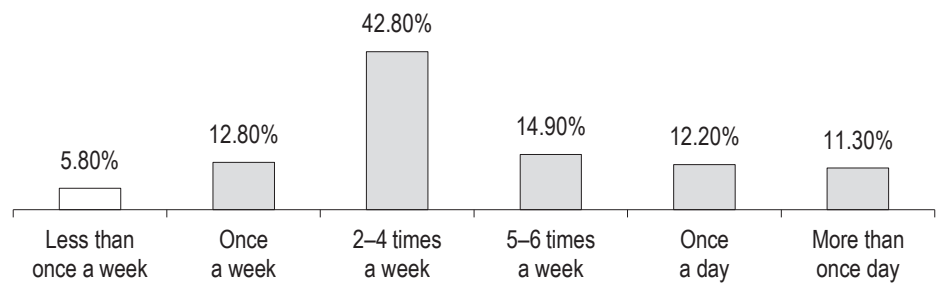

Figure 5 . Frequency of fruit consumption per week

Source: own study.

The data from Figure 6 shows that only $3.7 \%$ of students eat fresh vegetables more often than once a day, $6.6 \%$ eat one portion per day, $50.4 \%$ eat them $2-4$ times a week, and $7.7 \%$ eat 5 to 6 times a week. A disturbing fact is that as many as $18.4 \%$ of the students eat fresh vegetables only once a week, and $13.1 \%$ less than once a week. 


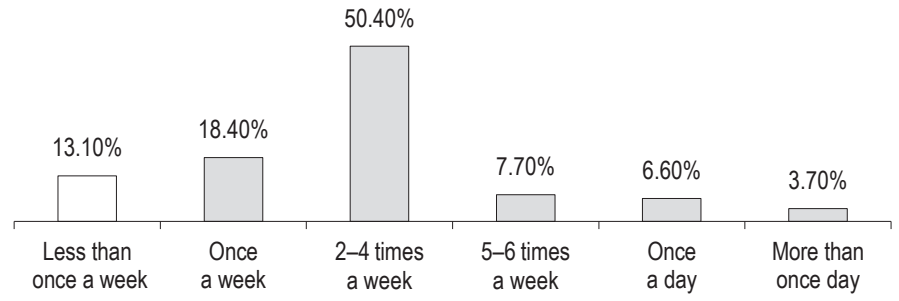

Figure $\boldsymbol{G}$. Frequency of consumption of vegetables or salads from fresh vegetables within a week

Source: own study.

When asked about the frequency of consumption of sweets and sugary drinks (Figure 7), almost 20\% of students declared every day, including $8.7 \%$ more than once a day, $42.1 \%$ eat sweets $2-4$ times a week, and $13.8 \%$ eat them from 5 to 6 times a week. Only $14.2 \%$ of students eat sweets once a week. In the study group there were also students who consumed them less often than once a week (9\%). Over half (50.2\%) of the students eat sweets while at home (during homework and free time), others eat them mostly during school time (25.7\%), and others both at school and at home (24.1\%) (Figure 8). The place of purchase of sweets for the majority of the students (53.2\%) are shops on the way to school, $17.3 \%$ buy in school shops or use sweet machines, and for $29.6 \%$ of students, sweets are bought by the parents (Figure 9).

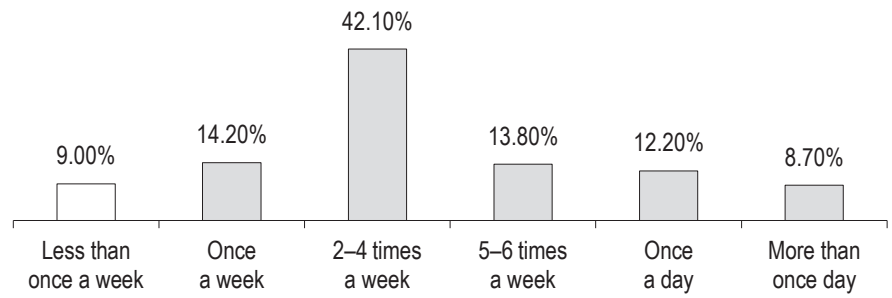

Figure 7. Frequency of sweets consumption (candies, chocolates, cookies, bars), cocoa or other sweetened beverages Source: own study.

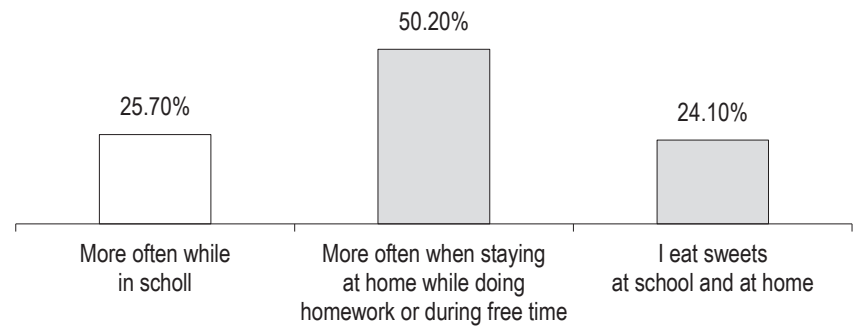

Figure 8. Time and place of the most frequent consumption of sweets and sweetened drinks

Source: own study. 


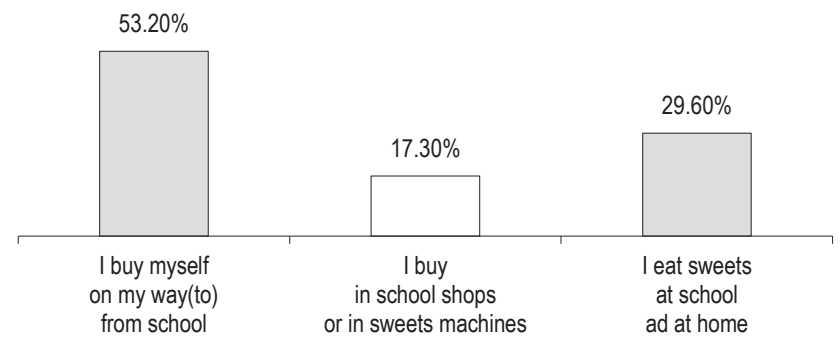

Figurle 9 . Place of purchase of sweets and sweet drinks consumed by the students Source: own study.

Almost $80 \%$ of students always participate in physical education classes, but $11.5 \%$ try to avoid this type of lesson, and $8.7 \%$ did not take part in such classes (Figure 10).

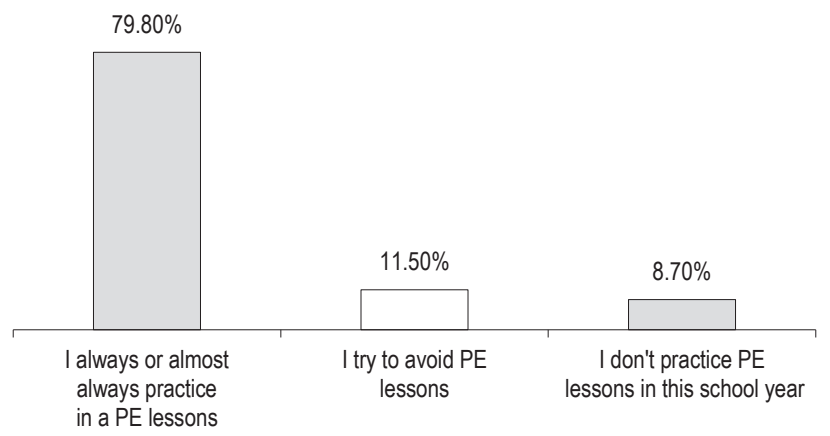

Figure 10. Frequency of participation in school physical education classes

Source: own study.

In addition to school lessons, $41.8 \%$ of students participate in other forms of physical activity under the care of a trainer, and $83.2 \%$ practice various forms of physical activities outside school PE lessons (cycling, swimming, running, playing football, etc.) (Figures 11, 12).

Physical exercise of high intensity is practiced daily by $24.7 \%$ of the students, with $45 \%$ practicing several times a week (15.8\% from 4 to 6 times, $30.5 \%$ from 2 to 3 times a week), $14.4 \%$ once a week, others once a month (6.0\%), less frequently than once a month (4.4\%) or never (4.2\%) (Figure 13). $10 \%$ of the students spend over 7 hours a week on exercise, $10.1 \%$ spend about $4-6$ hours, and $24.1 \%$ spend about $2-3$ hours. The largest number of students (27.3\%) spend about an hour on additional physical activity, $16.6 \%$ less than an hour (about half an hour). As much as $11.4 \%$ do no exercise at all (Figure 14). 


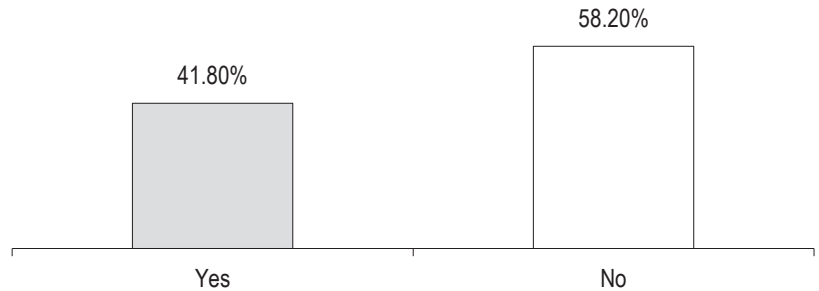

Figure 11. Participation in organized forms of physical activity under the supervision of an instructor, trainer outside school PE lessons

Source: own study.

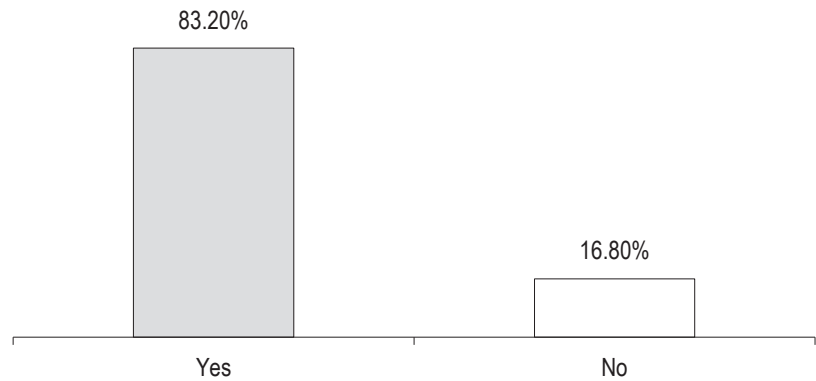

Figure 12. Practicing various forms of sports (cycling, swimming, running, playing football, etc.) outside school PE lessons Source: own study.

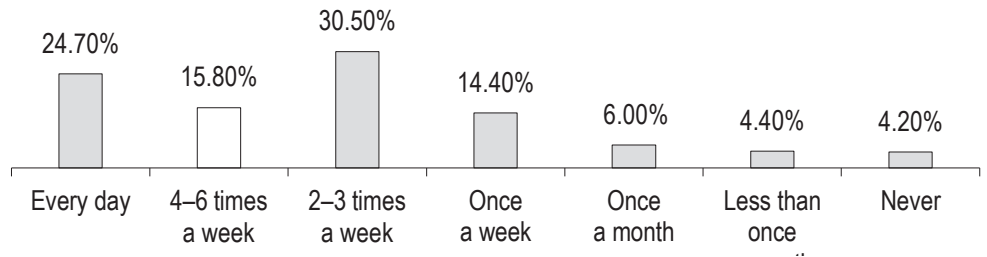

Figure 13. Frequency of intense physical exercise

Source: own study. 


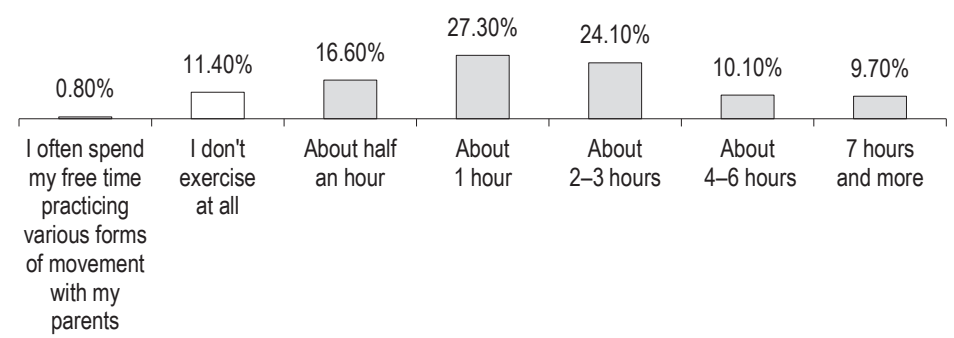

Figure 14. Time spent on additional high intensity physical activity

Source: own study.

Over $45 \%$ of students never engage in physical activity with their parents, some only exercise from time to time with both parents $(17.5 \%)$ or only with one of their parents $(6.2 \%$ only with father, $6.4 \%$ only with mother). Only $12.7 \%$ of the students spend time doing physical activity together with their parents, $6.2 \%$ only with their mother and 5.7 only with their father (Figure 15).

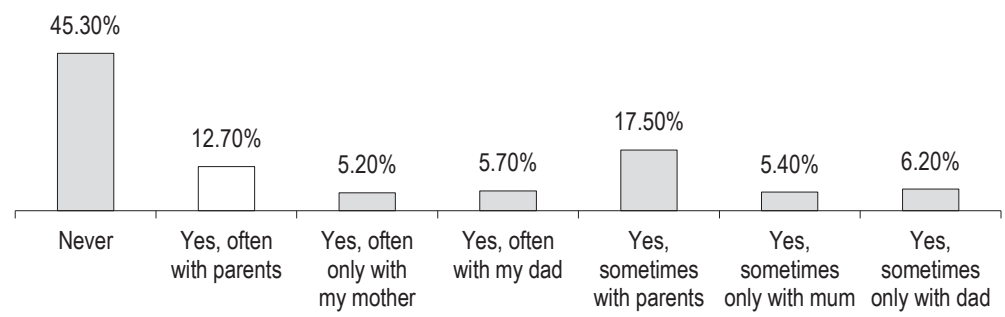

Figure 15. Parent participation in common physical activity

Source: own study.

The questionnaire also included questions about the physical activity of the parents of the students. The obtained answers indicate that both mother and father of over $50 \%$ of students engage in physical activity during the week (minimum once a week (2-3 times, 4-6 times a week or daily). Unfortunately, some parents only practice once a month, less than once a month or never (Figures 16, 17).

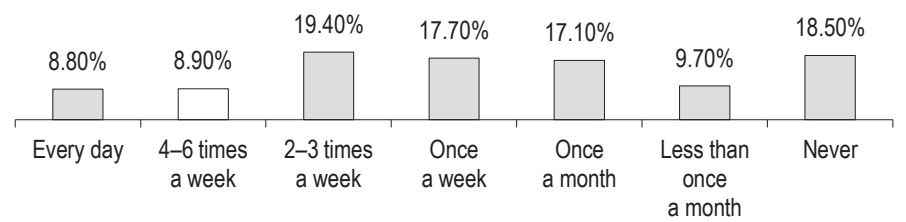

Figure 16. Frequency of physical activities by the mothers of the students

Source: own study. 


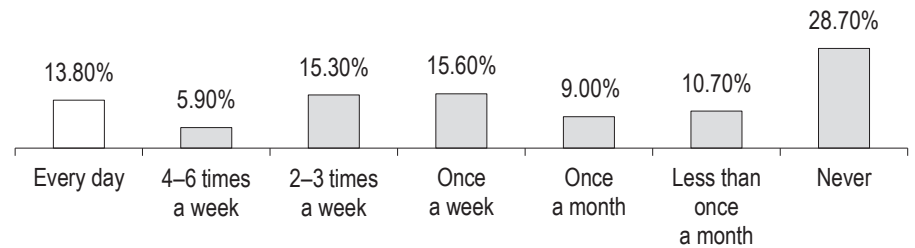

Figure 17. Frequency of physical activities by the fathers of the students

Source: own study.

Almost $30 \%$ of the students examined have a swimming card, $25 \%$ can swim (backstroke, any, classic style), $23 \%$ do not swim but can float and not sink. As many as $18 \%$ of students cannot swim and $4.7 \%$ are afraid of going into the water (Figure 18).

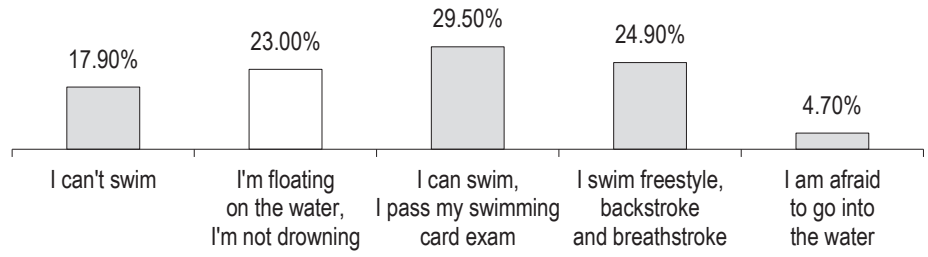

Figure 18. Assessment of swimming skills by students

Source: own study.

Thirty-seven percent of students would be interested in participating in a "WOPR Youth Team", acquiring the rights of a WOPR Junior Lifeguard and becoming a volunteer leader in the Team activities. $35 \%$ did not want to participate, while other students were undecided ("I do not know") (Figure 19).

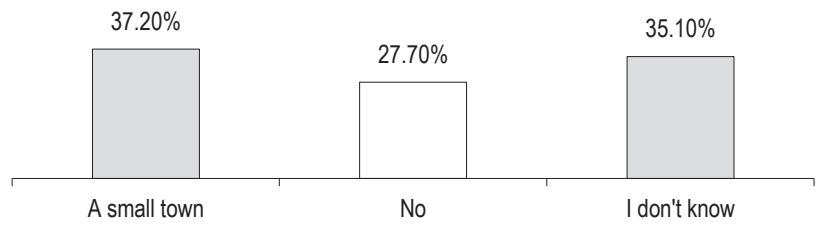

Figure 19. Student interest in participating in a "WOPR Youth Team", acquiring the rights of a WOPR Junior Lifeguard and becoming a volunteer leader in the Team activities

Source: own study. 
The average BMI of the students examined was 22.58 and did not differ significantly between the students from cities of different sizes. The highest mass and height was characteristic of students from very large cities, with the lowest fat mass and the highest fat-free and muscle mass (resulting in the highest body weight). Students from small, medium and large cities with a higher fat mass had a lower lean and muscle mass than students from very large cities (Figures 20, 21, 22, 23, 23, 24, 25).

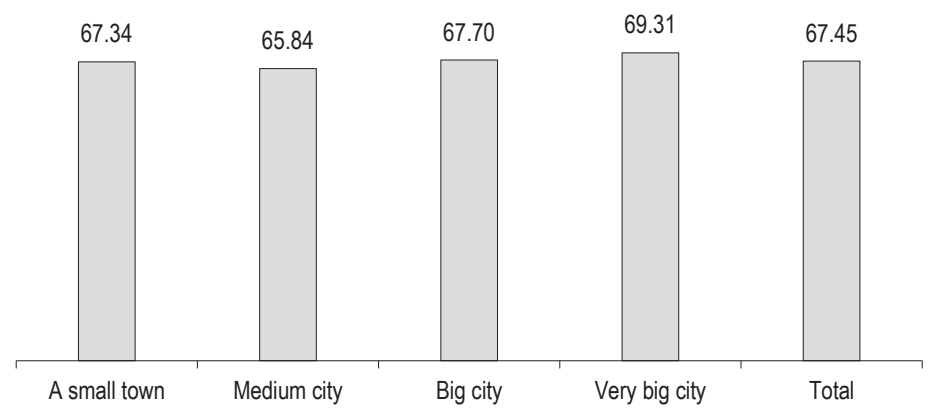

Figure 20. Body mass of students in individual districts, taking into account the number of inhabitants $(\mathrm{kg})$ Source: own study.

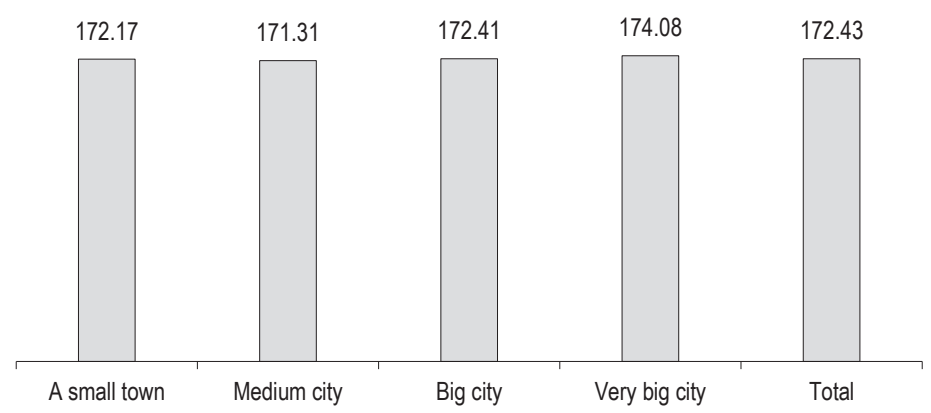

Figure 21. Height of the students in individual districts, taking into account the number of inhabitants (cm) Source: own study. 


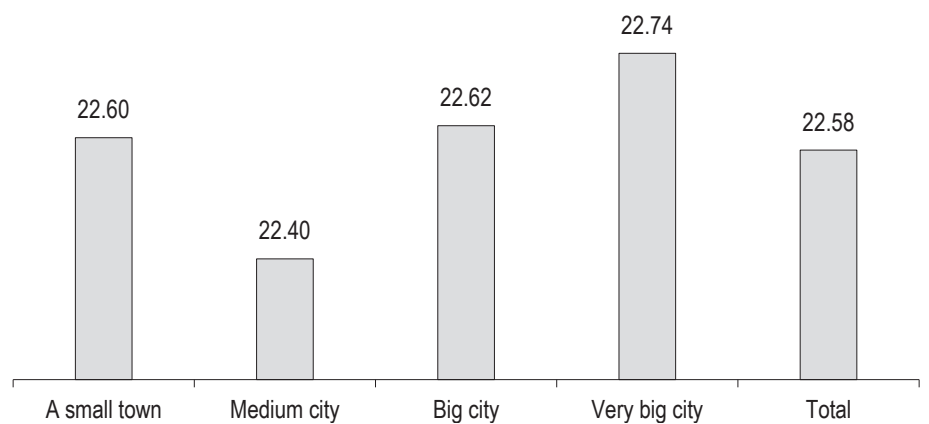

Figure 22. BMI of the students in individual districts, taking into account the number of inhabitants Source: own study.

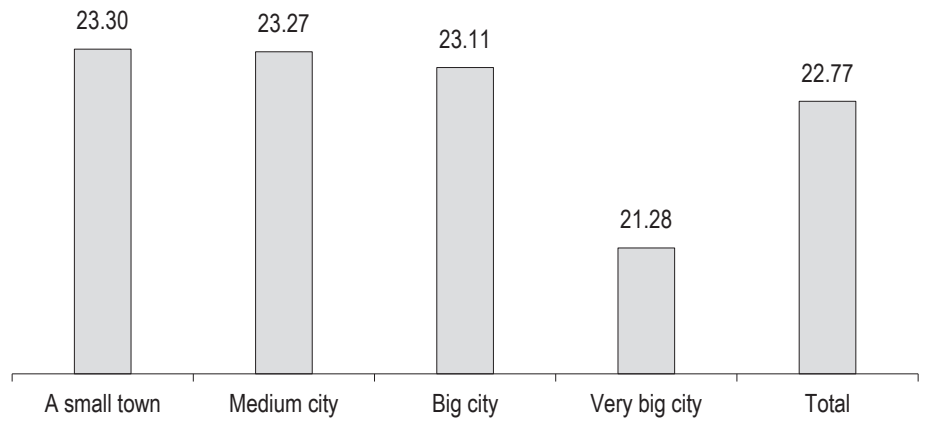

Figure 23. Fat mass of the students in individual districts, taking into account the number of inhabitants (\%) Source: own study.

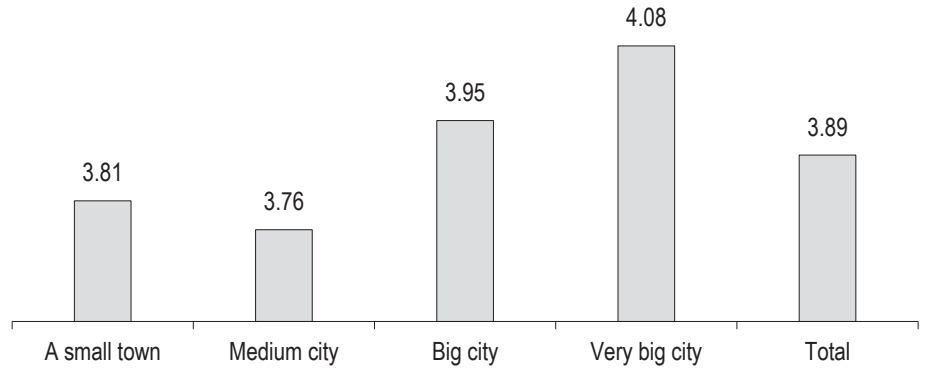

Figure 24. Lean mass of the students in individual districts, taking into account the number of inhabitants Source: own study. 


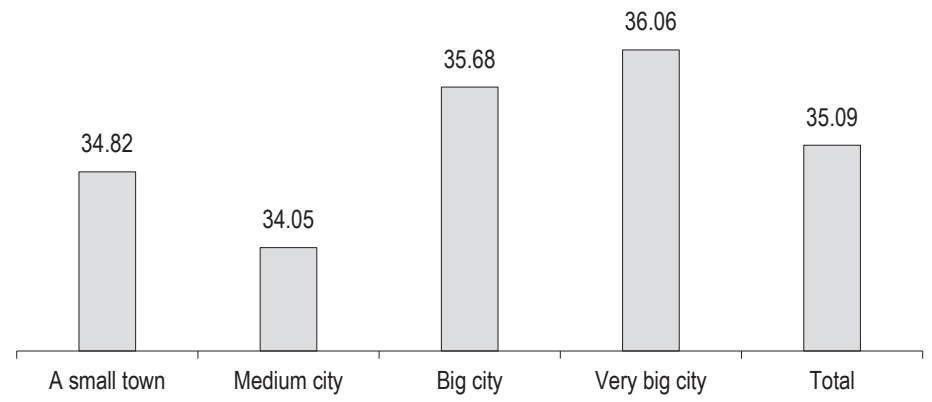

Figure 25. Muscle mass of students in particular districts, taking into account the number of inhabitants Source: own study.

\section{Discussion}

Proper nutrition that provides essential nutrients and the right amount of energy determines the appropriate body weight, proper growth and both physical and mental development of school-age children. Changes occurring during puberty cause an increase in interest in corporeality and external appearance, which may also contribute to various, not necessarily correct, dietary shifts. Incorrect nutrition increases the risk of developing many civilization diseases such as obesity, type II diabetes, cardiovascular disease and some cancers. The most common adolescent dietary irregularities include too few vegetables and fruits, milk and milk beverages, dark bread, with a high consumption of sweet drinks, sweets, and salty snacks. Nutritional mistakes made are associated with a low level of health education. Research carried out in various places in Poland show many mistakes in the diet of the adolescents examined.

In the presented study, a frequent dietary mistake was the lack of breakfast on school days, with the majority of breakfasts being on the days off school. Similar results were obtained by the 2010 HBSC research in which only $52.2 \%$ of high school students in Poland eat breakfast every school day, and as many as $26.6 \%$ do not eat breakfast at all. At the weekends, $82.8 \%$ of students declared eating breakfast. The results regarding the amount of vegetables and fruit consumed, as well as sweets and sugary drinks in both studies showed too little vegetables and fruits in the diet, with a high consumption of sweets and sugary drinks (Raport techniczny...).

Also, in studies conducted among students of Warsaw high schools (mainly from general schools), it was shown that the majority of students eat 3-4 meals a day, do not eat breakfast, and the vegetables in their diet are only in the dinner meal. A relationship between the number of meals and gender was shown. In the female diet, just 2 meals a day was more prevalent, while the boys more often consumed 6 meals or more during the day. In the study, $84 \%$ of students consumed snacks between meals (Czarniecka-Skubina, Namysław, 2008). Also, in the study conducted by E. Sikora, T. Leszczyńska and P. Szymański (2007), most students (85\%) eat snacks between meals - mainly fruit, sandwiches and chips.

In studies carried out by I.M. Batyk (2012) as many as 5\% of students consumed only one meal a day, $15 \%$ of students have two meals, $45 \%$ have breakfast, $25 \%$ have no breakfast. In the diet, $62.5 \%$ of students have a second breakfast, however, most often in the form of sweet rolls, sandwiches and sweets, which also indicates 
a high sugar intake by the students. Over half $(65 \%)$ of the students eat snacks between meals. Of the students studied, as many as $56.5 \%$ eat fast-food products every day.

According to other researchers (Czarniecka-Skubina, Namysław, 2008; Czarnocińska, Wadołowska, Dymkowska, Szelc, 2001; Gacek, Fiedor, 2005; Kowieska, Biel, Stanisławski, 2007), adolescents usually consume 3-4 meals a day. According to G.C. Rampersaud et al. (2005), 30\% of adolescents aged 15-18 do not eat breakfast, with girls most often. According to B. Szczepaniak et al. (2002), about $12-14 \%$ of teenagers eat too few meals during the day.

As a result of research carried out by M. Wojtaś and A. Kołajtis-Dołowy (2011) it was found that the diet of high school students is not very varied, and most meals are sandwiches. As in the presented study, a low intake of vegetables, fruits and dairy products by the study group was demonstrated. Most of the students kept the right time between the last meal and the time of going to sleep. Only $40 \%$ of students declared eating breakfast every day. In spite of their normal weight, students chose diets with reduced caloric value (Wojtaś, Kołłajtis-Dołowy, 2011). This may be due to the fact that adolescents often have difficulty with a proper body weight assessment, describing it as abnormal (Kołoło, Woynarowska, 2004). Many national and European studies point out that perceiving your body weight as high may be the reason for different psychophysical problems (Ter Bogt et al., 2006) and uncontrolled transition to various diets and the belief in the necessity of their use (Kołoło, Woynarowska, 2004; Ojala, Tynjälä, Välimaa, Villberg, Kannas, 2012).

The research carried out on students of high schools in the Mazowieckie Voivodship shows that a large part of the surveyed youth skip meals and eat irregularly. Only $47 \%$ of students eat a minimum of 4 meals or more. The study discussed above yielded different results on vegetable consumption - only $2.6 \%$ of students do not eat them, $47.5 \%$ eat them often. Physical activity of the students was also examined and it was shown that almost half of the students show insufficient physical activity, and it is more often abandoned by girls. Only $25 \%$ of students participate in sports activities outside of school lessons (Saracen, 2010).

Analysis of selected nutritional behaviors of students from the Świętokrzyskie Voivodship showed that more than a half consume from 4 to 5 meals a day, about $1 / 3$ of students eat only three or fewer meals, only $3 / 4$ of students eat dinner every day. As in the previously described studies, the majority of students (as much as $91.8 \%$ ) declare snacking (Gajda, Jeżewska-Zychowicz, 2010).

The presented research in this paper and the analysis of other studies show that the nutrition of young people is often irrational and unsuitable for their developmental age.

\section{Conclusion}

1. Evaluation of the diet of the students showed a lot of irregularities in a significant number of adolescents, as indicated by skipping breakfast, too few fresh vegetables and fruits, and frequent consumption of sweets and sugary drinks.

2. Nutritional mistakes can be made by a lack of time on school days (eating breakfast for a much larger percentage of students on days off-school) and the availability of unhealthy products in the school shop (purchase of sweets in school shops).

3. Nutritional education for young people and intense health promotion in order to correct dietary mistakes and shape correct habits should be introduced. 
4. Most students show adequate physical activity during school and outside school. A small percentage of people engage in physical activity together with their parents.

5. Despite the irregularities in eating habits, the average BMI of the tested students was correct.

\section{References}

Barry, E.L. (2000). The obesity epidemic. Obes. Res., 8, 342-347.

Batyk, I.M. (2012). Zwyczaje Żywieniowe wśród młodzieży. J Health Sci, 2 (5), 7-13.

Brytek, A. (2005). Pandemia otyłości. Terapia, Uzależnienia i Współuzależnienia, 1 (40), 27-29.

Czarniecka-Skubina, E., Namysław, I. (2008). Wybrane elementy zachowań żywieniowych uczniów szkół średnich. ŻNTJ, 6 (61), 129-143.

Czarnocińska, J., Wądołowska, L., Dymkowska, M., Szelc, M. (2001). Edukacja żywieniowa a dojadanie między posiłkami przez młodzież z Technikum Gastronomicznego. Nowiny Lekarskie, 70 (9), 1043-1049.

Dzielska, A., Kołoło, H., Mazur, J. (2008). Zachowania zdrowotne młodzieży związane z odżywianiem w kontekście czynników społeczno-ekonomicznych - kierunek zmian w latach 2002-2006. Probl Hig Epidemiol, 89 (2), 222-229.

Epstein, L.H. (1996). Family-based behavioural intervention for obese children. Int. J. Obes., 20 (supl. 1), s14-s21.

Gacek, M., Fiedor, M. (2005). Charakterystyka sposobu odżywiania się młodzieży w wieku 14-18 lat. Rocz. PZH, 56 (1), 49-56.

Gajda, R., Jeżewska-Zychowicz, M. (2010). Zachowania żywieniowe młodzieży mieszkającej w województwie świętokrzyskim wybrane aspekty. Probl Hig Epidemiol, 91 (4), 611-617.

Gawęcki, J., Roszkowski, W. (2009). Żywienie człowieka a Zdrowie Publiczne. T. 3, pp. 223-228. Warszawa: PWN.

Gould, R., Russell, J., Barker, M.E. (2006). School lunch menus and 11 to 12 years old children's food choice. In three secondary school in England are the nutritional standards being met? Appetite, 46 (1), 86-92.

Gronowska-Senger, A. (2001). Współczesne problemy żywieniowe dzieci szkolnych w Polsce. Żywność, 3, 28-35.

Gronowska-Senger, A. (2007). Żywienie, styl życia a zdrowie Polaków. Żyw Człow Metab, 34, $12-21$.

Hamułka, J., Gronowska-Senger, A., Tomala, G. (2002). Częstotliwość i wartość energetyczna śniadań spożywanych przez młodzież szkół ponadpodstawowych. Roczn PZH, 53 (1), 81-89.

Harton, A., Sa'eed Bawa, Weker, H. (2002). Przyczyny nadwagi i otyłości prostej u młodzieży w wieku 13-15 lat - aspekt żywieniowy. Żyw. Człow. Metab., 29, Supl., 226-230.

llow, R., Rogulska-llow, B., Sarzała-Kruk, D., Biernat, J. (2008). Ocena zwyczajów żywieniowych licealistów z Oleśnicy. Bromatol Chem Toksykol, 3, 705-710.

Jarosz, M., Bułhak-Jahymczyk, B. (2008). Normy żywienia człowieka. Warszawa: PZWL.

Jeżewska-Zychowicz, M. (2004). Ocena poziomu wiedzy żywieniowej młodzieży w wieku 13-15 lat w perspektywie prewencji chorób dietozależnych. Żyw. Człow. Metab., 31, Supl., cz. II, 86-98.

Jeżewska-Zychowicz, M. (2007). Zachowania żywieniowe i ich uwarunkowania. Warszawa: SGGW.

Knapik, A., Plinta, R., Saulicz, E., Kuszewski, M. (2004). Znaczenie aktywności ruchowej w profilaktyce zdrowotnej. Zdr Publ, 114 (3), 331-337.

Kołoło, H., Woynarowska, B. (2004). Samoocena masy ciała i odchudzanie się młodzieży w okresie dojzzewania. Przegląd Pediatryczny 2004, $34(3 / 4), 196-201$.

Korczak, C.W. (2000). Profilaktyka i edukacja prozdrowotna młodzieży w XXI wieku. Probl Hig, 68, 19-25.

Kowieska, A., Biel, W., Stanisławski, A. (2007). Zwyczaje żywieniowe i czynniki wyboru żywności wśród młodzieży szkoły średniej. Żyw. Człow. Metab., 34 (1/2), 727-732.

Nosko, J. (1990). Zachowania a zdrowie: podstawowe zależności. Aktywność fizyczna a zdrowie. In: A. Gniazdowski (ed.), Zachowania zdrowotne. Zagadnienia teoretyczne, próba charakterystyki zachowań zdrowotnych społeczeństwa polskiego. Łódź: Instytut Medycyny Pracy.

Ojala, K., Tynjälä, J., Välimaa, R. Villberg, J., Kannas, L. (2012). Overweight Adolescents' Self-Perceived Weight and Weight Control Behaviour: HBSC Study in Finland 1994-2010. Journal of Obesity, May 28.

Rampersaud, G.C., Pereira, M.A., Girard, B.L., Adams, J., Metzl, J.D. (2005). Breakfasts Habits, Nutritional Status, Body Weight, and Academic Performance in Children and Adolescents. J. Am. Diet. Assoc., 105 (5). 
Raport techniczny - Wyniki badań - HBSC 2010, Instytut Matki i dziecka. Retrieved from: http://www.parpa.pl/images/file/hbsc_rap12010.pdf (30.06.2018).

Riddoch, Ch. (1998). Young and active? Policy framework for young people and health-enhancing physical activity. Health Educ Authority, Londyn.

Saracen, A. (2010). Zachowania zdrowotne młodzieży szkół ponad gimnazjalnych. Hygeia Public Health, 45 (1), 70-73.

Sikora, E., Leszczyńska, T., Szymański, P. (2007). Share of fast food products in dietary behaviour of young people. Pol. J. Food Nutr. Sci., 57 (3), 373-380.

Świderska-Kopacz, J., Marcinkowski, J.T., Jankowska, K. (2008). Zachowania zdrowotne młodzieży gimnazjalnej i ich wybrane uwarunkowania. Cz. IV. Sposób żywienia. Probl Hig Epidemiol, 89 (2), 241-245.

Szczepaniak, B., Flaczyk, E., Górecka, D. (2002). Częstotliwość spożycia wybranych produktów w zależności od sytuacji materialnej młodzieży. Żyw. Człow. Metab., 29, Supl., 137-142.

Szewczyński, J.A., Ostrowska, A., Gajewska, M. (2005). Charakterystyka posiłków młodzieży szkół średnich z Warszawy. Żyw Człow Metab, 32, suppl., 801-805.

Szponar, L., Rychlik, E. (2000). Żywienie zbiorowe dzieci i młodzieży szkolnej w Polsce. Roczn PZH, 51 (2), 149-154.

ter Bogt, T.F., van Dorsselaer, S.A., Monshouwer, K., Verdurmen, J.E., Engels, R.C., Vollebergh, W.A. (2006). Body mass index and body weight perception as risk factors for internalizing and externalizing problem behaviour among adolescents. Journal of Adolescent Health, 39 (1), 27-34.

Trujillo, E., Davis, C., Milner, J. (2006). Nutrigenomics, proteomics, metabolomics, and the practice of dietetics. J Am Diet Assoc, 106, 403-413.

Ward-Begnoche, W.L., Gance-Cleveland, B. (2005). Promoting Behavioral Change in Overweight Youth. J. Pediat. Health Care, 19 (5), 318-328.

Wierzbicka, E., Roszkowski, W. (2005). Ocena spożycia żywności z uwzględnieniem produktów typu „fast food” w wybranej grupie młodzieży. Bromatol Chem Toksykol, suppl. 561-566.

Wierzbicka, E., Stosio, A. (2007). Spożycie produktów typu „fastfood” przez wybraną grupę młodzieży szkolnej z rejony Warszawy. Żyw Człow Metab, 3 (1/2), 182-187.

Wojtaś, M., Kołłajtis-Dołowy, A. (2011). Zachowania żywieniowe wybranej grupy uczniów ostatnich klas szkół ponad gimnazjalnych w Warszawie. Probl Hig Epidemiol, 92 (4), 947-950.

Zasady Prawidłowego Żywienia (2016). IŻŻ, Warszawa 2016. Retrieved from: http://izz.waw.pl/zasady-prawidowego-ywienia (30.06.2018).

Zielona Księga - Promowanie zdrowego żywienia i aktywności fizycznej: europejski wymiar zapobiegania nadwadze, otyłości i chorobom przewlekłym. Komisja Wspólnot Europejskich, Bruksela 2005.

Zimna-Walendzik, E., Kolmaga, A., Tafalska, E. (2009). Styl życia - aktywność fizyczna, preferencje żywieniowe dzieci kończących szkołę podstawową. ŻNTJ, 4 (65), 195-203.

Żołnierczuk-Kieliszek, D. (2002). Zachowania zdrowotne i ich związek ze zdrowiem. In: T.B. Kulik, M. Latalski (eds), Zdrowie publiczne. Lublin: Czelej.

Cite this articlle aS: Ratajczak, J., Rucińska, K., Kolbowicz, M., Zalewski, T. (2020). Selected Nutritional Behaviors and the Level of Physical Activity of High School Students. Central European Journal of Sport Sciences and Medicine, 3 (31), 59-74. DOI: 10.18276/cej.2020.3-05. 